\title{
人工膝関節全置換術後患者の歩行自立日数に影響を及ぼす要因
}

\author{
一術前項目による検討一
}

\section{Factors that affect the period to get a gait in patients after total knee arthroplasty -Focusing on preoperative factors-}

\author{
廻角 侑弥 ${ }^{1,2)}$ ，久保 峰鳴 ${ }^{1,2)}$ ，幸田 仁志 ${ }^{3)}$ ，福本 貴彦 ${ }^{2)}$ \\ 今北 英高 ${ }^{2}$, 藤井 唯誌 ${ }^{4)}$, 稲垣 有佐 ${ }^{5)}$, 田中 康仁 ${ }^{5)}$
}

Yuya Mawarikado, ${ }^{1,2)}$, Takanari Kubo, ${ }^{1,2)}$, Hitoshi Koda ${ }^{3)}$, Takahiko Fukumoto ${ }^{2)}$

Hidetaka Imagita $^{2)}$, Tadashi Fujii ${ }^{4)}$, Yusuke Inagaki ${ }^{5)}$, Yasuhito Tanaka ${ }^{5)}$

要旨：[目的] 人工膝関節全置換術後患者の杖歩行が自立するまでの日数 (歩行自立日数) に影響を及ほす要因を術前項目より検討した。[対象］片側の人工膝関節全置換術を施行 した99名とした。［方法］測定項目は歩行自立日数，自己効力感，痛みの破局的思考，安 静時痛, 歩行時痛, 膝関節屈曲可動域および伸展可動域, 等尺性膝伸展筋力, 歩行速度と した。統計解析はピアソンの相関係数を用いて歩行自立日数との関係性を分析し，また歩 行自立日数を目的変数，他項目を説明変数とした重回帰分析を行った。[結果］歩行自立 日数は, 自己効力感 $(r=-0.40)$, 痛みの破局的思考 $(r=0.27)$, 等尺性膝伸展筋力 $(r$ $=-0.24)$, 歩行速度 $(\mathrm{r}=-0.25)$ との間に有意な相関関係を認めた。重回帰分析の結果, 歩行自立白数に影響を及ぼす要因として自己効力感のみが抽出された。[結語］人工膝関 節全置換術後の杖歩行の自立には筋力や歩行速度だけでなく，自己効力感が影響すると示 唆された。

キーワード : 人工膝関節全置換術, 歩行, 自己効力感

\begin{abstract}
Purpose] The purpose of this study was to investigate preoperative factors that affect gait in patients after total knee arthroplasty (TKA). [Subjects] Ninety-nine patients after TKA. [Methods] Measurement outcomes were the period to get a gait, Japanese version of the modified gait efficacy scale (mGES), pain catastrophizing scale (PCS), rest pain, walking pain, the range of motion of knee flexion and extension, isokinetic knee extension strength and normal walking speed. In statistical analysis, the relationship between the period to get a gait and preoperative factors was evaluated using Pearson's correlation coefficient. Stepwise multiple regression analysis was used to evaluate the dependent variable of gait, factors that showed a significant difference in the comparison of gait as independent variable. [Results] Pearson's correlation coefficient indicated the preoperative factors related to gait were mGES $(r=-0.40)$, PCS $(r=0.27)$, isokinetic knee extension strength $(\mathrm{r}=-0.24)$ and normal walking speed $(\mathrm{r}=-0.25)$. The multiple regression analysis indicated that mGES affect the period to get a gait among other factors. [Conclusion] These results showed that not only muscle strength and walking speed but also mGES affect the number of gait days in patients after TKA.
\end{abstract}

Key words: Total knee arthroplasty, Gait, Self-efficacy

受付日：2020年 4 月 2 日, 採択日：2020年 4 月27日

社会医療法人高清会 香芝旭ヶ丘病院 リハビリテーション科：テ639-0265 奈良県香芝市上中 839 番地

電話：0745-77-8101, FAX : 0745-78-5090

E-mail : b9972384@kio.ac.jp

Department of Rehabilitation, Kashiba Asahigaoka Hospital : 839 Kaminaka, Kashiba-city, Nara 639-0265, Japan TEL: +81-745-77-8101, FAX: +81-745-78-5090

2) 畿央大学大学院健康科学研究科

Graduate School of Health Science, Kio University

3) 関西福祉科学大学保健医療学部リハビリテーション学科

Department of Rehabilitation Sciences, Faculty of Allied Health Sciences, Kansai University of Welfare Sciences

社会医療法人高清会 香芝旭ヶ丘病院 整形外科

Department of Orthopaedic Surgery, Kashiba Asahigaoka Hospital

奈良県立医科大学整形外科学教室

Department of Orthopaedic Surgery, Nara Medical University 


\section{I 、はじめに}

本邦における変形性膝関節症の有症状患者数は約 800 万人と試算されている ${ }^{1)}$ 。人工膝関節全置換術 (Total Knee Arthroplasty：TKA）は，変形性膝関節症 患者の疼痛を改善させ，活動性や生活の質を高める有 効な治療法であり，その手術件数は年々増加傾向にあ る。しかし，近年では医療費削減を目的に入院日数の 短縮が推し進められており ${ }^{2)}$, TKA 術後の入院日数 も短縮傾向にある。

退院するうえで日常生活動作の自立が必要であり, TKA 術後患者では入院日数と杖歩行が自立するまで の日数（歩行自立日数）との間に強い相関関係がある と報告されている3.4)。よって，杖歩行の早期獲得に向 けて，歩行が自立するまでの日数に関連する因子を明 らかにする必要がある。な扮，術後歩行自立日数の予 測には術後理学療法からの検討では遅く, 術前理学療 法の評価項目からの検討が必要である 3.5 .6$)$

先行研究では, TKA 術後の歩行自立日数に関連す る術前因子として，大腿四頭筋筋力 ${ }^{7}$ や片脚立位時間 ${ }^{5)}$, $10 \mathrm{~m}$ 歩行時間 $\left.{ }^{8}\right)$, Timed up and go test ${ }^{6.8)}$ との有意な相 関関係があると示されている。しかし，TKA 術後の 患者では, 身体機能の低下に加えて, 疼痛への固執や 予後に関する不安を抱くと報告されている ${ }^{9}$ 。 の施行により膝関節構造をはじめとした身体機能が改 善するものの，心理的側面には直接的に介入できない ため, 術後の歩行の獲得には術前の自己効力感が影響 している可能性がある。

歩行動作を安全に行うことができるか否かに対する 自信の程度を把握するための評価指標として, 日本語 版 modified Gait Efficacy Scale（日本語版 mGES）が 用いられている。健常高齢者では歩行能力が高い者ほ ど日本語版 mGES が高い結果であったと報告されて いる(10)。したがって, 日本語版 mGES の得点が TKA 術後の早期歩行自立に関連することが考えられるが, これらの関係性を分析した報告は見当たらない。

そこで本研究は，TKA 術後の杖歩行が自立するま での日数に及ぼす影響を，日本語版 mGES を含む術 前要因より検討することとした。

\section{II. 対象と方法}

\section{1. 対 象}

2019年 5 月から 2020年 1 月の期間で，当院にて片側 TKA を施行された99名を対象とした。対象者99名の うち, 男性は 18 名, 女性は81名, 年齢は $73.7 \pm 7.2$ 歳,

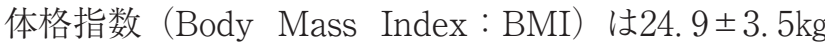
$/ \mathrm{m}^{2}$ であった。除外対象は, 術前評価時に独歩また は杖での自立歩行ができない者, 精神疾患の診断をう けている者，再置換術を施行する者とした。本研究は， 香芝旭ヶ丘病院研究倫理委員会の承認（承認番号： 2019051-003）を得た上で実施した。また，対象者に はヘルシンキ宣言に則り, 研究の主旨・目的を書面に て説明し同意を得た上で実施した。

\section{2. 方 法}

\section{1 ）歩行自立日数と入院日数}

歩行自立日数は手術日の翌日を術後 1 日目として換 算し，病院内を杖歩行で移動自立と担当理学療法士が 判断するまでの日数とした。入院日数は，手術日の翌 日を術後 1 日目として換算し，退院するまでの日数と した。歩行自立日数と入院日数は，電子カルテより後 方視的に追跡し記録した。

2 ) 術前の評価項目

背景因子は，年齢，BMI とした。アンケート評価 として, 日本語版 mGES, 痛みの破局的思考（Pain Catastrophizing Scale：PCS）を患者の自記式で実施 した。身体機能評価として, 安静時痛, 歩行時痛, 膝 関節屈曲可動域，膝関節伸展可動域，等尺性膝伸展筋 力，通常歩行速度を測定した。年齢㧍よびBMI は電 子カルテより後方視的に追跡し記録した。

日本語版 mGES は，歩行に対する自己効力感の評 価として用いた。本法はリッカート尺度で回答する自 己効力感の質問紙評価であり，その信頼性と妥当性は 報告されている ${ }^{10,11)}$ 。質問項目は，床板のような固い 平面上，芝生の上，通路の障害物の回避，縁石の上り， 縁石の下り，手すりを用いた階段昇降，手すりを用い ない階段昇降（昇段と降段は別項目），長距離歩行（約 800m）の10項目の歩行環境条件で構成されている。 各質問に対して安全に歩くことができるかを 1 （No Confidence：まったく自信がない) から10 (Complete Confidence：完全に自信がある）の10段階で回答し， その合計得点（得点範囲：10～100点）を算出して用 いた。

PCS は, 反颎, 無力感, 拡大視の 3 つの下位尺度 からなる自己記入式の評価尺度である ${ }^{12)}$ 。普段痛みを 感じている自分の状態にどの程度当てはまるかを各項 目 5 件法で回答し，得点が高いほど破局的思考が強い ことを示す。各項目の回答は 0 点から 4 点で行い, 全 13項目の合計得点を算出した。 
疼痛評価には, Visual Analog Scale を用いた ${ }^{13)} 。 100$ $\mathrm{mm}$ の物差しスケールの両端を「0：痛みなし」と 「100：今までに経験したことのないような強い痛 み」とし, 安静時と歩行時それぞれの疼痛強度を示す よう対象者に指示した。

膝関節屈曲可動域および伸展可動域は, 日本リハビ リテーション医学会が定める測定方法に従い実施した。 測定にはゴニオメーターを使用し, 自動運動で術側の 膝関節屈曲可動域掞よび伸展可動域を計測した。

等尺性膝伸展筋力の測定は, 徒手筋力計 (アニマ社 製, ミュータス F-100）を用いて, 加藤らの方法 ${ }^{14)} に$ 従い, 被検者を端座位で膝関節 $90^{\circ}$ 屈曲位とし, 徒手 筋力計のセンサー部を下腿遠位部に設置し，治療ベッ ドの支柱にベルトで固定した状態で最大等尺性筋力を 測定した。術側の筋力を 2 回測定し, その平均值を体 重で除した值（kgf/kg）を用いた。

通常歩行速度は, 対象者が普段歩いている楽な速さ で歩行した時間をストップウォッチにて計測した。測 定区間は $10 \mathrm{~m}$ とし, 測定区間の両端に $3 \mathrm{~m}$ ずつの予 備路を設けた歩行路で測定を行い，測定区間内の歩行 所要時間から速度 $(\mathrm{m} / \mathrm{s})$ に換算した。それぞれ 2 回 測定し平均值を採用した。

\section{3 ) 統計学的解析}

歩行自立日数と術前因子との関係，ならびに歩行自 立日数と入院日数との関係をピアソンの積率相関係数 を用いて検討した。さらに，歩行自立日数を従属変数， 単相関分析の結果で歩行自立日数と有意な相関関係が 認められた術前因子を独立変数としてステップワイズ 法による重回帰分析を実施した。なお，統計解析には IBM SPSS17.0を用いて解析し, 有意水準は $5 \%$ とし た。

\section{III. 結 果}

対象者の背景因子と術前評価項目の平均值を表 1 に 示す。歩行自立日数は $11.3 \pm 3.3$ 日, 入院日数は 16.9 土3.9日であった。

歩行自立日数と有意な相関関係が認められた術前因 子は, 日本語版 $\operatorname{mGES}(\mathrm{r}=-0.40, \mathrm{p}<0.01), \mathrm{PCS}$ $(\mathrm{r}=0.27, \mathrm{p}<0.01)$ ，等尺性膝伸展筋力 $(r=-0.24$, $\mathrm{p}<0.05)$, 通常歩行速度 $(r=-0.25, \mathrm{p}<0.05)$ で あり, 年齢, BMI, 安静時および歩行時痛, 膝関節屈 曲可動域および伸展可動域との間に有意な相関関係は 認められなかった (表 2 )。また, 歩行自立日数と入 院日数は有意な相関関係 $(r=0.66, p<0.01)$ を認め
表 1 背景因子と術前評価項目の記述統計値

\begin{tabular}{|c|c|c|c|}
\hline & 平均值 & \pm & 標準偏差 \\
\hline 歩行自立日数（日） & 11.3 & \pm & 3.3 \\
\hline 入院日数（日） & 16.9 & \pm & 3.8 \\
\hline 年齢（歳） & 73.7 & \pm & 7.2 \\
\hline $\operatorname{BMI}\left(\mathrm{kg} / \mathrm{m}^{2}\right)$ & 24.9 & \pm & 3.5 \\
\hline 日本語版 mGES（点） & 48.5 & \pm & 21.4 \\
\hline PCS（点） & 27.7 & \pm & 11.8 \\
\hline 安静時痛（mm） & 15. 2 & \pm & 21.5 \\
\hline 歩行時痛（mm） & 46.7 & \pm & 24.9 \\
\hline 膝関節屈曲可動域（度） & 123.7 & \pm & 16.6 \\
\hline 膝関節伸展可動域（度） & -8.5 & \pm & 6.5 \\
\hline 等尺性膝伸展筋力 $(\mathrm{kgf} / \mathrm{kg})$ & 0.2 & \pm & 0.1 \\
\hline 通常歩行速度（m/s） & 0.9 & \pm & 0.2 \\
\hline
\end{tabular}

BMI : Body Mass Index,

日本語版 mGES : 日本語版 - 改訂 Gait Efficacy Scale,

PCS : Pain Catastrophizing Scale

表 2 背景因子および術前評価項目の相関関係

\begin{tabular}{lc}
\hline & 歩行自立日数 \\
\hline 入院日数 & $0.66^{* *}$ \\
年齢 & 0.19 \\
$\mathrm{BMI}$ & -0.04 \\
日本語版 mGES & $-0.40^{* *}$ \\
$\mathrm{PCS}$ & $0.27^{* *}$ \\
安静時痛 & -0.14 \\
歩行時痛 & 0.12 \\
膝関節屈曲可動域 & -0.19 \\
膝関節伸展可動域 & -0.08 \\
等尺性膝伸展筋力 & $-0.24^{*}$ \\
通常歩行速度 & $-0.25^{*}$ \\
\hline
\end{tabular}

${ }^{* *} \mathrm{p}<0.01, \quad{ }^{*} \mathrm{p}<0.05$

BMI : Body Mass Index,

日本語版 mGES：日本語版－改訂 Gait Efficacy Scale,

PCS : Pain Catastrophizing Scale

表 3 歩行自立日数に影響する関連因子

\begin{tabular}{lccc}
\hline & 標準化係数 & 有意水準 & $\mathrm{R}^{2}$ \\
\hline 日本語版 mGES & -0.401 & 0.01 & 0.16 \\
\hline
\end{tabular}

た。

歩行自立日数を従属変数, 単相関分析で歩行自立日 数と有意な相関関係が認められた術前因子を独立変数 として投入した重回帰分析の結果，日本語版 mGES $(\beta=-0.401, \mathrm{p}<0.01)$ のみが影響する因子として 抽出された (表 3$)$ 。

\section{IV. 考 察}

本研究は, TKAの術前因子から術後の歩行自立日 数に及ぼす影響について検討することを目的に調査し 
た。日本語版 mGES の得点は $48.5 \pm 21.4$ 点であった。 牧迫ら ${ }^{10)}$ の報告による健常高齢者の得点は $80.2 \pm 14.0$ 点であったことから, 本研究の対象者は健常高齢者よ りも歩行に対する自信が低下しており，歩行に影響を 及ぼしている可能性が高い。

単相関分析の結果, 歩行自立日数と入院日数の間に は有意な相関関係を認めた。竹本ら ${ }^{15}$ は, TKA 術後 に抢けるT字杖歩行の早期獲得は理学療法に扔ける退 院可能条件の期間を短縮する要因となると述べている。 また，石原ら ${ }^{3)}$ は TKA 術前・後の評価項目で，入院 日数に影響を及ぼす因子は歩行自立日数のみであった と述べている。このことから, 本研究も先行研究を支 持する結果となり, TKA 術後に抢ける杖歩行の早期 獲得は入院日数の短縮に慗がる可能性が高い。

歩行自立日数と関係する術前因子として，西川ら ${ }^{5}$ は歩行自立日数と年齢および片脚立位時間との間に有 意な相関関係を認めたと述べている。また，能村ら は術測大腿四頭筋筋力の改善が重要であると述べてお り, 飛山ら ${ }^{8)}$ は $10 \mathrm{~m}$ 歩行時間や Timed up and go test といった歩行能力が歩行自立日数に関連すると報告し ている。本研究においても歩行自立日数と等尺性膝伸 展筋力ならびに通常歩行速度との間には相関関係を認 め, 術後の歩行自立日数には下肢筋力ゃバランス能力, 歩行能力といった身体機能因子が関係していることが 推察される。

また, 本研究における歩行自立日数は, 自己効力感 評価である日本語版 mGES との間に中等度の相関関 係 $(r=-0.40)$ を認め, その関係性は歩行自立日数 と歩行速度との関係（ $\mathrm{r}=-0.25 ）$ より大きかった。 自己効力感は身体活動や運動促進に関わる要因として 考えられいる ${ }^{16)}$ 。また自己効力感は身体活動や運動行 動などの予測因子として働くと報告されている ${ }^{17)}$ よって, TKA 術前の歩行に対する自信の程度が術後 理学療法の歩行練習の自信に反映し, 杖歩行の獲得時 期に影響したと推察される。

重回帰分析の結果，歩行自立日数に影響する術前因 子として抽出されたのは日本語版 mGES のみであっ た。先行研究では, 歩行獲得には身体機能が影響する ことが多数報告されてきたが5-8)，これらの項目は歩 行自立日数に影響する要因として抽出されなかった。 本研究における各項目の測定は TKA 施行前に実施し たため, 歩行速度が平均 $0.9 \pm 0.2 \mathrm{~m} / \mathrm{s}$ とフレイルの 基準 $(1.0 \mathrm{~m} / \mathrm{s}$ 未満) を下回っており, 対象者全体の 歩行能力が低下していた。一方, 日本語版 mGES の
平均は $48.5 \pm 21.4$ 点と対象者間のばらつきが大きく, 歩行能力が低下していても歩行に対する自信の高い者 と低い者が混在していた。よって，TKA 術後の杖歩 行自立日数を予測するうえで，歩行に対する自己効力 感を測定する必要性があると示唆された。

以上のことから，日本語版 mGES は歩行自立日数 と関連し，またTKA 術後の歩行自立日数に影響する ことが示された。今後, さらなる入院日数の短縮が求 められる社会情勢の中で，適切な医療を提供していく ことが求められる。その中で, TKA 術後では歩行速 度や身体機能の改善に加えて, 術前の自己効力感の把 握が重要となる可能性がある。ただし，本研究では術 前の各項目が術後どのように変化したか詳細な分析が できていない。今後は，各項目の術前・術後の值を縦 断的に分析し，歩行自立日数に影響する術前要因をよ り検証する予定である。

\section{引用文献}

1）吉村典子：変形性膝関節症の疫学 - 変形性関節症診療の新 たな展開一. Pharma Medica, 2017，35(6)：13-17。

2）厚生労働省：病院の病床利用率・平均在院日数, 病床の種 類 $\times$ 都道府県 - 指定都市 - 特別区 - 中核市 (再掲) 別. https://www.mhlw.go.jp/toukei/saikin/hw/iryosd/18/dl/ 03byouin30.pdf（2020/3/12引用）

3）石原奈美，川合直美，関根利江 - 他：人工膝関節全置換術 術後患者の在院日数に影響を及ぼす因子について。臨床理 学療法研究, 2010, 27：67-69.

4）梅原拓也, 田中亮, 長尾進・他：変形性膝関節症に罹患し て人工滕関節置換術を受けた患者の在院日数に術前㧍よび 術後の運動介入が及ぼす影響ーランダム化比較試験に対す るシステマティックレビューおよびメタアナリシス - . 理 学療法の臨床と研究, 2014, 23: 7-12

5）西川徹, 南角学, 宮坂淳介-他：人工膝関節置換術施行患 者の歩行度と下肢筋力の関連性について - 変形性膝関節症 と関節リウマチ患者の比較一。理学療法京都，2010，39： 85-89.

6）眞田祐太朗，椎木孝幸，森本毅・他：人工膝関節全置換術 施行前の身体機能が術後の歩行および入院期間に及ぼす影 響。理学療法科学, 2014, 29(2)：197-200.

7）能村恵美，赤尾健志，寺林恵美子 - 他：全人工膝関節置換 術後の歩行能力予測について, みんなの理学療法, 2005, 17, 51-53

8）飛山義憲, 山田実, 和田治 - 他：人工膝関節置換術後の早 期杖歩行獲得に挹ける運動機能予測因子の検討。第51回近 畿理学療法学術大会抄録集. $2010: 10$.

9）平川善之, 原道也, 藤原明・他：術後痛の慢性化に影響す る認知的・精神的因子の検討. PAIN RESEARCH，2013， 28(1), 23-32

10）牧迫飛雄馬, 島田裕之, 吉田大輔 - 他 : 日本語版一改訂 Gait Efficacy Scaleの信頼性㧍よび妥当性. 理学療法学, 
2013, 20(2) : 87-95.

11) Newell AM,VanSwearingen JM,Hile E,et al: The modified Gait Efficacy Scale; establishing the psychometric properties in older adults. Phys Ther, 2012, 92: 318-328.

12）松岡紘史, 坂野雄二 : 痛みの認知面の評価 : Pain Catastrophizing Scale 日本語版の作成と信頼性および妥当性の検 討. 心身医学, 2007, 47: 95-102.

13) McCormack HK,Horne DJ,Sheather S : Clinical Applications of Visual Analogue Scales: A Critical Review. Psychol Med, 1988, 18: 1007-1019.

14）加藤宗規, 山崎裕司, 柊幸伸 ·他 : ハンドヘルドダイナモ メーターによる等尺性膝伸展筋力の測定. 総合リハ, 2001, 29(11)：1047-1050.

15）竹本民樹, 西村真人, 大久保裕介 - 他 : 当院での人工膝関 節全置換術 2 週間クリニカルパスの可能性についてー理学 療法の視点から一。理学療法学, 2007, 34: 139.

16）坂野雄二, 前田基成, 川原健資・他：セルフエフィカシー の臨床心理学. 北大路書房, 京都2002, 218-233.

17) Bandura A: Self-efficacy: toward a unifying theory of behavior change. Psychol Rev, 1977, 84: 195-215. 